\title{
Improving Production of Liquid Smoke from Candlenut Shell by Pyrolisis Process
}

Sulhatun

\author{
Department of Chemical Engineering, University of Malikussaleh, Lhokseumawe \\ City, Aceh, Indonesia \\ Rosdanelly Hasibuan and Hamidah Harahap \\ University of North Sumatera, Medan City, North Sumatera, Indonesia \\ Iriani \\ Department of Chemical Engineering, University of North Sumatera, Medan City, \\ North Sumatera, Indonesia \\ Herman Fithra \\ Department of Civil Engineering, University of Malikussaleh, Lhokseumawe City, \\ Aceh, Indonesia
}

\begin{abstract}
Purpose - The purpose of this research is to study the process conditions that give best yield and expected compositions of liquid smoke products that result during the pyrolisis process relying on predetermined variables.

Design/Methodology/Approach - Pyrolisis process running times are varied, that is, 0.5, 1, 1.5, 2, 2.5, 3, $3.5,4,4.5,5,5.5$, and 6 hourly. Condensing temperature maintained remained $25-30^{\circ} \mathrm{C}$. Products identification was applied by using gas chromotography mass spectroscopy.

Findings - Based on the research output, it was concluded that process conditions which give maximum yield were achieved when using double unit condenser (DUC) and time optional four hours, and it provides maximum volume liquid smoke product, and compositions of pyrolisis products. The process also created seven components, namely nepthalene, propanoic acid, 3,7 nanodiena, 2 metilguaiakol, 2-metoksi 4-methyl phenol, 4 ethyl-2 metoksil phenol, oxybanzene. Applying DUC during condensation phase may increase condensing force thereafter obtaining resulted products between $200 \%$ and $300 \%$ rather than using single unit condenser (SUC).

Research Limitations/Implications - This research was conducted on a fixed batch reactor made of a metal plate with a thickness of $3.0 \mathrm{~mm}$. It carries $200 \mathrm{~kg}$ in capacity. In this phase, the moisture of candlenut shells might be kept in $10-12.5 \%$ wt. Process temperature applied ranged within $350-500{ }^{\circ} \mathrm{C}$.
\end{abstract}

The authors would like to thank and respect the Department of Research and Technology of Indonesia and KEMENRISTEK DIKTI, who have contributed and supported this research financially, thereby accomplishing this research accordingly.

(C) Sulhatun, Rosdanelly Hasibuan, Hamidah Harahap, Iriani, Herman Fithra. Published in the Emerald Reach Proceedings Series. Published by Emerald Publishing Limited. This article is published under the Creative Commons Attribution (CC BY 4.0) licence. Anyone may reproduce, distribute, translate and create derivative works of this article (for both commercial and noncommercial purposes), subject to full attribution to the original publication and authors. The full terms of this licence may be seen at http://creativecommons.org/licences/by/4.0/legalcode

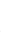


Proceedings of MICoMS 2017
Originality/Value - In addition the study increased the theorical of understanding about pyrolisis process and Improving the production of liquid smoke from candlenut shell by pyrolisis process using the method of vapor condensation (Double unit condensor).

Keywords Candlenut shell, liquid smoke, pyrolisis, single unit condenser, double unit condenser

All papers within this proceedings volume have been peer reviewed by the scientific committee of the Malikussaleh International Conference on Multidisciplinary Studies (MICoMS 2017).

\section{Introduction}

Hazel nut or candlenut (Aleurites moluccana) is classified as one of the huge available natural resources in Indonesia, being considered as a wide prospect marketing commodity both in domestic and overseas. Candlenut shell resulted from its plantations is claimed as one of the numerous solid waste biomass, containing organic compounds, such as hemicelluloses, cellulose, and lignin.

Utilizing waste of biomass as the source of bio oil or liquid smoke thorough pyrolisis are commonly used. Thus, by using several raw materials, such as coconut shells (Haji et al., 2007), palm stems, empty fruit bunches of palm (Fahlepy and Suwardin, 2015), palm shell, saw dust, straw, wheat, grass (Bridgwater, 2010), pine nut shells (Darmadji, 1996), jatropha seeds, Karanja Niger seeds (Purnima, 2012), pine woods, corn cob (Chen et al., 2016), date seeds, coconut husks, plum seeds, waste residue, etc. However, utilizing solid waste materials from candlenut shells to be processed resulting liquid smoke through pyrolisis process are reported never applied.

Characteristic of pyrolisis products consisting of liquid smoke as a prime product, bio char as a solid state product resulted in tar and gas (Shen et al., 2015). Hereafter, compositions gained by biomass pyrolisis process are classified by its chemical prosperities, thus phenol, carbonil compound, formaldehyde, acid compound, and hydro polisiklis aromatis (HPA) such as benzo (@) pyrene in which claimed badness due to carsinogenic formed in wood pyrolisis process.

Liquid smoke has potential use for all natural antimicrobial in commercial aplication where smoke flavor is desired, which uses in food aplication (Saloko et al., 2014; Soazo et al., 2016), because liquid smoke memiliki manfaat sebagai antihydroxidative and antimicrobial (Ricke- and Crandall, 2014). The smoking of meat has been used as a presentitative technique for centuries (Kan et al., 2015). Redestillasi liquid smoke from oil palm shell has been proven effective as fresh fish preservative due to its antibacterial activity (Chen and Lin, 2015). Latex coogulant is one of the important factor of natural rubber because it will deremine the quality of rubber end product. One of the coogulant which produces good quality natural rubber is liquid smoke (Fahlepy and Suwardin, 2015).

The purpose of this research was to find out (i) treatment procedures which result in best yield, (ii) composition of of liquid smoke yielded from pyrolisis process using predetermined variables, and (iii) the effect of double unit and single unit condenser (SUC) on yield improvement of liquid smoke using pyrolisis process.

\section{Materials and Methods}

This research conducted in several stages, starting from raw material preparation (candlenut shell) that was harvested from several villages plantations within North Aceh district.

\subsection{Raw material preparation}

The raw material is using candlenut shell. This is collected by locals from several villages in north Aceh resort. It is dried naturally by sun to reduce moisture content around $10-15 \%$ (Figure 1). 


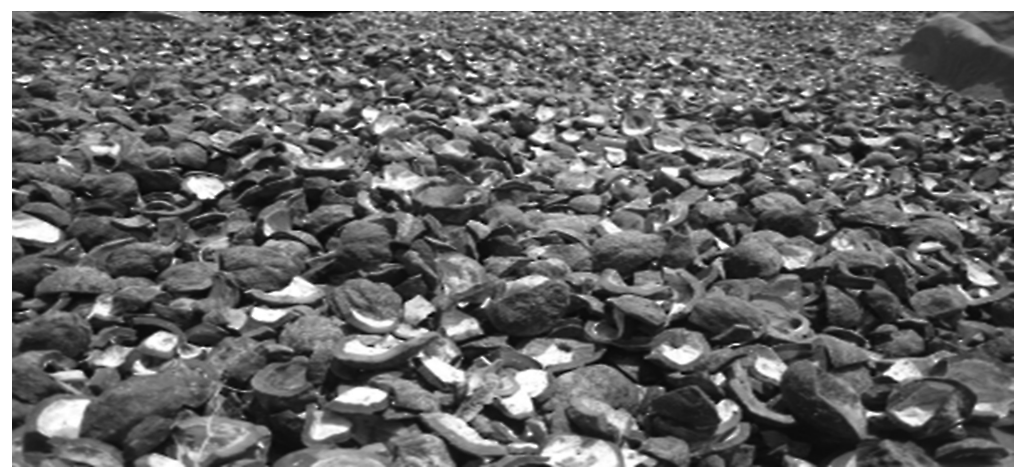

Production of Liquid Smoke

Figure 1.

The Raw Material of Candlenut Shell

\subsection{Pyrolisis Stage Methode}

In this phase, dried candlenut shells to be weighed at $200 \mathrm{~kg}$ and fed into pyrolisis tube of reactor which is made up of metal plate with thickness in $3 \mathrm{~mm}$. In this stage, humidity of candlenut shells should be kept at 10-12.5\% and not to be crushed to smaller size as it has been appropriately sized. Process temperature maintained within $350-550{ }^{\circ} \mathrm{C}$. Time of pyrolisis presets, that is, $0.5,1.0,1.5,2.0,2.5,3.0,3.5,4.0,4.5,5.0,5.5$, and 6 hourly. Pyrolisis equipments to be used are SUC and double unit condenser (DUC) intended to observe comparatively the effects of both condensers upon condenser increasing efficiency of pyrolisis products obtained. Hereafter, the products collected into storage tank. Condensing temperature to be kept at $25-30{ }^{\circ} \mathrm{C}$. The next step is to identify the products by using gas chromotography mass spectrometry (GCMS). Calibration of area chromatoghraphy to be done by analyzing response factors over chemical group appearances which firstly determined by using campuran standard and senyawa reference (untuk cairan Tetraline untuk gas methane) with a very concentrations. Unidentified peaks of chromatography. Figure 2 covers a $5 \%$ of total area presented by average response factor. Characteristic of

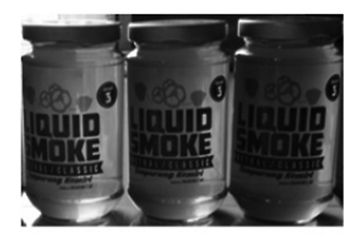

\section{Liquid Smoke}

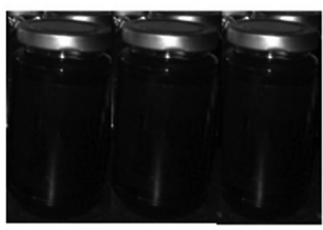

Tar

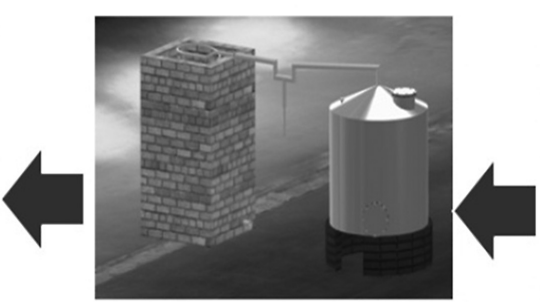

PYROLISIS DUC/SUC

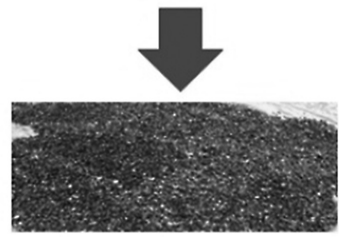

Char

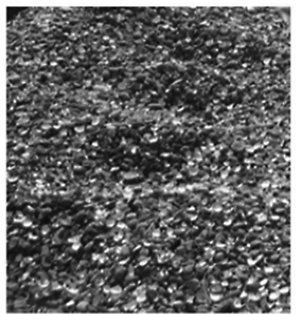

Candlenut Shell
Figure 2.

The Schematic

Diagram of

Candlenut Shell

Pyrolisis Process

Using Fix Batch

Reactor DUC and

SUC 
Proceedings of liquid products may observed by using Carlo Elba EA 1108 that equipped with elemental MICoMS 2017 microanalyzer. By this instrument, a liquid smoke-water mixture can be observed (Carl Fische Technic, Iram 21320). Calorie value of liquid product-gas mixture to be corrected depending on water content calculated by Dulong's method (Figure 2).

146

\subsection{Product analysis stage}

Hence we undertook the identification of liquid smoke product yielded by optimum condition and evaluated the characteristics of the product with several variables. GCMS was applied in identifying products. Moreover, analyzing stage was followed by measuring acidity.

\section{Results and discussion}

\subsection{Result}

3.1.1. Pyrolisis Condition. Optimum process condition on candlenut shells resulting maximum gain of liquid smoke by pyrolisis, by applying vapor condensing method, using DUC and SUC with running time 1, 1.5, 2, 2.5, 3, 3.5, 4, 4.5, 5, 5.5, and 6 hourly. It shown in Figure 4, where best performance of pyrolisis process to achieve maximum quantity of liquid smoke derive from candlenut shells resulted by using DUC within running time four hours and for SUC within 3.5 hours.

3.1.2 Affection of condenser's types upon increasing yield of liquid smoke. Optimum process conditions resulting maximum liquid smoke product in pyrolysis of candlenut shells by applying vapor condensing method of SUC that takes pyrolysis running time four hours. Best performance process conditions achieved by applying DUC with running time four hours in which total yield of liquid smoke obtained around 1,320 mL. It is clearly shown in Figure 3.

Figure 3.

Graph Effect

Condensor SUC and DUC Serta

\section{Graph Efect type condensor} upon \% increasing liquid smoke product after

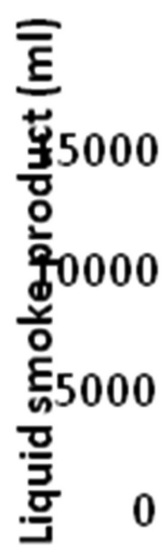


The percentage increase of the candlenut shell liquid smoke products using double-type condensor showed significant influence towards smoke liquid production compare to using single-type condensor. The increase reached $300 \%$. It can be seen in Figure 3.

3.1.3. Product Analisa Stage. Analisa identification of the product by GCMS dapat dilihat pada Table 1.

3.2. Discussion

Optimum process condition on candlenut shells resulted in maximum gain of liquid smoke by pyrolisis, by applying vapor condensing method using DUC and SUC with running time $1,1.5,2,2.5,3,3.5,4,4.5,5,5.5$, and 6 hourly. It is shown in Figure 4, that the best performance of pyrolisis process to achieve maximum quantity of liquid smoke derived from candlenut shells resulted by using DUC within running time of four hours and for SUC within 3.5 hours.

\begin{tabular}{lll}
\hline No. & \multicolumn{1}{c}{ Name Komponen } & $\%$ Area \\
\hline 1 & Oxybenzene & 2,36 \\
2 & Propanoic acid & 2.26 \\
3 & 2-Methoxy phenol & 73,44 \\
4 & 2-Methoxy-4-methyl-phenol & 13,05 \\
5 & 8-Methyl-3,7-nonadien-2-one & 3.12 \\
6 & 4-Ethyl-2-methoxy-phenol & 2.58 \\
7 & Naphthalene & 3,19 \\
& & 100
\end{tabular}

Production of Liquid Smoke

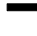


Proceedings of Analisa Identification of The product by GCMS can be seee in Table 1. The compositions of MICoMS 2017 pyrolisis liquid smoke obtained are also created seven components, namely nepthalene, propanoic acid, 3,7 nanodiena, 2 metilguaiakol, 2-metoksi 4-methyl phenol, 4 ethyl-2 metoksil phenol, oxybanzene. Dari grafik diatas juga dapat dilihat kandungan atau persen fenol yang tinggi terdapat pada asap cair tempurung kemiri sebesar 73,44\%.

\section{$148 \quad 4$. Conclusion}

From this research, the conclusion can be described as follows:

The best process condition for maximum performance of liquid smoke during pyrolisis of candlenut shell with condensing vapor method was by using SUC at 3.5 hours and DUC at 4 hours, respectively, which obtained total yield araound $456 \mathrm{~mL}$ and $13,200 \mathrm{~mL}, \mathrm{pH} 4.23-$ 4.78 condensing mechanism using the type of condensor DUC obtained liquid smoke product is higher than using the type of condensor SUC. The increasing percentage liquid smoke candllenut shell was obtained by using DUC to $300 \%$.

Identification of products by using GCMS at optimum conditions shows that liquid smoke candlenut shell consists of components such as oxybenzene $2.36 \%$, propanoic acid 2.26\%, 2-methoxy phenol 73,44\%, 2-methoxy-4-methyl-phenol 13.05\%, 8-methyl-3,7nonadien-2-one 3.12\%, 4-ethyl-2-methoxy-phenol $2.58 \%$, and dan nepthalene $3.19 \%$.

\section{References}

Achmady, S.S., Mubarik, N.R., Nursyamsyi and Septiaji. (2013). "Characterization of Redistilled Liquid Smoke of Oil: Palm Shell and its Aplication as Fish Preservatives". Journal of Applied Science, Vol. 13, pp. 401-408.

Bridgwater, A.V. (2010). "Review of Fast Pyrolysis of Biomass and Product Upgrading”. Biomass and Bioenergy, Vol. 38, pp. 68-94.

Chen, D., Chen, X., Sun, J., Zheng, Z. and Fu, K. (2016). "Pyrolysis Polygeneration of Pine Nut Shell: Quality of Pyrolysis Products and Study on the Preparation of Activated Carbon from Biochar". pp. 629-636.

Chen, W.H. and Lin, B.J. (2015). "Characteristics of Products from the Pyrolysis of Oil Palm Fiber and its Pellets in Nitrogen and Carbon Dioxide Atmospheres". Energy, Vol. 94, pp. 569-578.

Darmadji, P. (2002). "Optimation of liquid smoke purification by redestilastion methode" Journal Teknologi dan Industri pangan Vol.XIII, no. 3 . pp. 267-271.

Darmadji, P. (2012). "Optimation of liquid smoke purification by encapsulation of coconut shell liquid smoke in chitosan - maltodekstrin based nanoparticle", pp. 73-179.

Fahlepy, A. and Suwardin, D. (2015). "Characterization of Iron Metal Corrosion in Liquid Smoke Coagulant". International Symposium on Aplied Chemistry, Procedia Chemistry Vol. 16, pp. 420426.

Gani, A.H., Abidin,Z., Mas'ud, Lay, B.W., Sutjahyo, S.H., and Puri, G. (2007). "Characterization of liquid smoke pyrolized from solid organic waste”, Journal teknik industri Pert, Vol 26, No. 3, pp. 111-118.

Haji, A.G., Mas'ud, Z.A., Lay, B.W., Sutjahyo, S.H. and Puri, G. (2007). "Characterization of Liquid Smoke Pyrolized from Solid Organic Waste”. Journal Tek. Ind. Pert, Vol. 26, No. 3, pp. 111-118.

Kan, T., Strezov, V., Evans, T.J. (2015). "Lignocellulosic Biomass Pyrolysis: A Review and Effects of Pyrolysis Parameters”. Renewable and Sustainable Reviews, Vol. 57, pp. 1126-1140.

Mabrouki, J., Abbassi, M.A., Guedri, K., Omri, A., Jeguirim, M. (2015). "Simulation of Biofuel Production via Fast Pyrolysis of Palm Oil Residues”. Fuel, Vol. 159, pp. 819-827.

Purnama, D. (2012). "Optimation of Liquid Smoke Purification by Encapsulation of Coconut Shell Liquid Smoke in Chitosan - Maltodekstrin Based Nanoparticle”. pp. 173-179. 
Ricke, S.C., Lingbeck, J.M., Cordero, P., O'Bryan, C.A., Michael, J., and Crandall, P.G. (2014). "Fucntionally of Liquid Smoke as an All-Natural Antimicrobial in Food Preservation". Meat Science, Vol. 97, p. 197.

Production of Liquid Smoke

Saloko, S., Darmadji, P., Setiadji, B. and Pranoto, Y. (2014). “Antioxidative and Antimicrobial Activies of Liquid Smoke Nanocapsule Using Chitosan and Maltodextrin and its Application on Tuna Fish Preservation”. Journal Since direct Food Bio science, Vol. 7, pp. 71-79.

Shadangi, K.P., Shadangi, K.P., Mohanty, K. (2015). "Co-Pyrolysis of Karanja and Niger Seeds with Waste Polystyrene to Produce Liquid Fuel”. Fuel, pp. 492-488.

Shen, J., Igathinathane, C., Yu, M. and Pothula, A.K. (2015). "Biomass Pyrolysis and Combustion Integral and Differential Reaction Heat with Temperatures using Thermogravimetric Analysis/ Differential Scanning Calorimetry". Journal Sincedirect Bioresource Technology Vol. 185, pp. 89-98.

Soazo, M., Perez, L.M., Piccirilli, G.N., Delorenzi, N.J. and Verdini, R.A. (2016). "Antimocrobial and PhysicoChemical Characterization of Whey Protein Concentrate Edible Films Incoporated with Liquid Smoke", Journal Sciencedirect food science and technology, Vol 72, pp. 285-291.

\section{Corresponding author}

Sulhatun can be contacted at sulhasiha@yahoo.com 